\title{
Antifungal and antibacterial activity and chemical composition of polar and non-polar extracts of Athrixia phylicoides determined using bioautography and HPLC
}

\author{
Lyndy Joy McGaw ${ }^{1 *}$, Victor Patrick Bagla ${ }^{1,2}$, Paul Anton Steenkamp ${ }^{3,4}$, Gerda Fouche ${ }^{3}$, Jana Olivier ${ }^{5}$,
} Jacobus Nicolaas Eloff ${ }^{1}$ and Martin Steven Myer $^{5}$

\begin{abstract}
Background: Athrixia phylicoides DC. (Asteraceae) is used medicinally in South Africa to treat a plethora of ailments, including heart problems, diabetes, diarrhoea, sores and infected wounds. It is also prepared in the form of a tea (hot decoction) taken as a refreshing, pleasant-tasting beverage with commercialization potential.

Methods: Extracts of the dried ground aerial parts were prepared using organic solvents (diethyl ether, dichloromethane/methanol, ethyl acetate and ethanol) and water. These extracts were subjected to HPLC, TLC and bioautography analysis with the aim of linking a range of peaks visualized in HPLC chromatography profiles to antibacterial and antifungal activity of the same extracts.

Results: HPLC revealed a group of compounds extracted by more than one solvent. Compounds identified include inositol, caffeic acid, quercetin, kaempferol, apigenin, hymenoxin and oleanolic acid. The organic extracts displayed similar TLC profiles, and bioautography indicated approximately five antibacterial compounds, but only two antifungal compounds in these extracts. Bioautography indicated that cold water extracted the least antimicrobial compounds.
\end{abstract}

Conclusions: Several previously unknown compounds were identified in Athrixia phylicoides extracts, and bioautography indicated a number of antibacterial and antifungal compounds. There were notable differences in chemical composition and bioactivity between the organic and aqueous extracts. Further research is necessary to fully characterize the active components of the extracts.

Keywords: Antibacterial, Antifungal, Asteraceae, Athrixia phylicoides, Bioautography, HPLC, Zulu tea

\section{Background}

Of the fourteen species of the genus Athrixia, nine are found in South Africa [1], including Athrixia phylicoides DC. (Asteraceae), which grows in mountainous and grassland areas of the eastern parts of South Africa [2]. Athrixia phylicoides, commonly known as bush tea or Zulu tea, is an aromatic leafy shrub with purple daisy-like flowers (Figure 1), growing mainly in grassland and forest margin

\footnotetext{
* Correspondence: lyndy.mcgaw@up.ac.za

'Department of Paraclinical Sciences, Phytomedicine Programme, Faculty of Veterinary Science, University of Pretoria, Private Bag X04, Onderstepoort 0110 , South Africa

Full list of author information is available at the end of the article
}

scrub regions. Following the commercial successes of the South African rooibos (Aspalathus linearis) and honeybush (Cyclopia spp.) teas, research into the potential commercialisation of Athrixia Zulu tea is being encouraged [3]. A recent survey of rural and urban dwellers in northern parts of South Africa revealed an active informal trade in the herb, used as a tea and for preparation of aromatic brooms from twigs stripped of leaves [4]. Rooibos and honeybush tea were originally drunk medicinally and then increasingly as a refreshing beverage, and it is envisioned that Athrixia tea may follow a similar path as an antioxidant-rich, caffeine-free tea [5-9]. In a review of research done on Athrixia phylicoides [3], it was concluded that in terms of

\section{Biomed Central}

(c) 2013 McGaw et al.; licensee BioMed Central Ltd. This is an open access article distributed under the terms of the Creative Commons Attribution License (http://creativecommons.org/licenses/by/2.0), which permits unrestricted use, distribution, and reproduction in any medium, provided the original work is properly cited. 


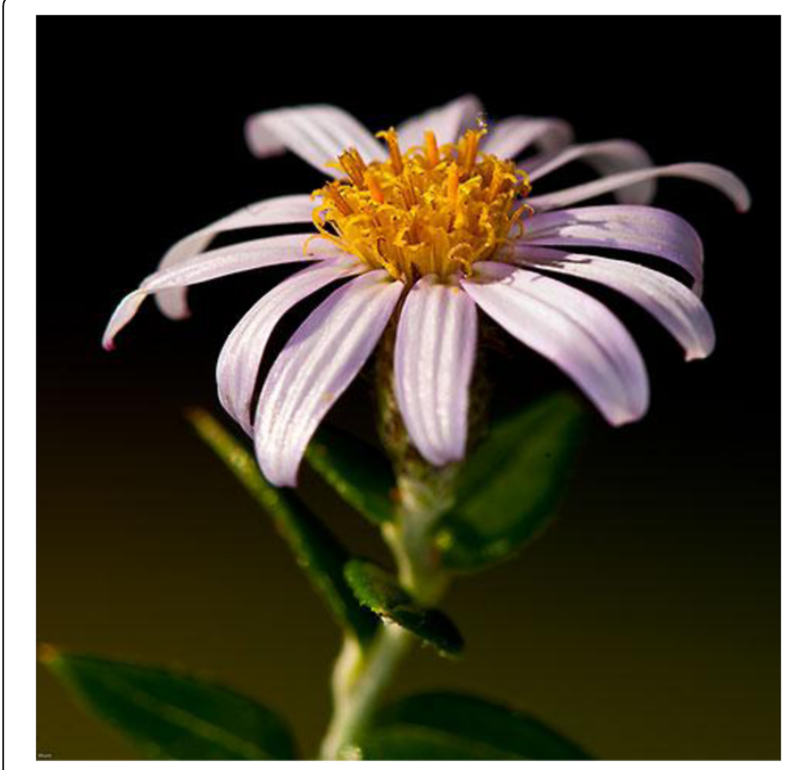

Figure 1 Athrixia phylicoides (photograph: Alvaro Viljoen), voucher number PRE 592582.0.

quality attributes and current use, Zulu tea has promising potential for development as a commercial product.

Decoctions and infusions prepared from the leaves and twigs of $A$. phylicoides are widely used by rural people to treat a variety of ailments, including sores, boils, acne, infected wounds [10], hypertension, circulation and heart problems, diabetes, diarrhoea, vomiting and skin conditions [4]. Leaf and root extracts are used as an anthelmintic [11] and as a remedy for cough [12], while root decoctions are used as a purgative [12]. A survey conducted in the Limpopo Province of South Africa revealed that Zulu tea is used to treat headaches, stomachache, influenza and leg wounds [13]. It is also used to cleanse the womb, kidney and veins and to purify blood [13]. The tea is purported to have stimulant and aphrodisiac properties [10,13,14]. A. phylicoides leaves and twigs are also prepared as a hot decoction and drunk as a pleasant-tasting, non-medicinal tea by indigenous South Africans. The preparation usually involves initially boiling a handful of broken leaves and twigs in approximately $1.5 \mathrm{~L}$ of water for $5 \mathrm{~min}$, after which the decoction is strained and served, usually without milk, and with sugar added to taste [4]. According to a recent survey, more rural and urban respondents use the plant as a tea rather than for medicinal purposes [4].

Biological activity studies on Athrixia phylicoides have concentrated on determining the antioxidant potential of the plant material as affected by time of year and other factors [5-9,15,16]. Antibacterial activity of the ethanol extract has been studied [6], together with antiinflammatory, antimicrobial and antimalarial properties of the methanol extract and essential oil [9]. A hot water extract of $A$. phylicoides twigs and leaves contained the phenolic compounds 6-hydroxyluteolin-7-O-glucoside, chlorogenic acid, protocatechuic acid, a di-caffeoylquinic acid and a methoxy-flavonol derivative [17]. This extract stimulated in vitro glucose uptake and metabolism, suggesting that consumption of the tea could potentially ameliorate metabolic disorders related to obesity and Type 2 diabetes mellitus [17].

Compounds isolated from $A$. phylicoides include chlorogenic acid, 1,3-dicaffeoylquinic acid, several hydroxycinnamic acid derivatives, including dicaffeoyl quinic acids, and an unidentified flavone-hexose as well as 6hydroxyluteolin-7-O-B-glucoside and quercetagetin-7-O-Bglucoside [15]. Other researchers [18] identified germacrene $\mathrm{D}$, linoleic acid and $p$-hydroxyphenylpropan-3-ol-coumarate, while a novel flavonol derivative, 5-hydroxy-6,7,8,3', $4^{\prime}, 5^{\prime}$ hexamethoxyflavon-3-ol has also been identified from the leaves of Athrixia phylicoides [3,19]. The same compound, as well as three more known flavonoids, namely 3-Odimethyldigicitrin, 5,6,7,8,3',4'-hexamethoxyflavone and quercetin, has been isolated from the ethanol extract of A. phylicoides aerial parts [7]. Three polymethoxylated flavones, quercetin-3'-O-glucoside, as well as a methoxylated derivative, two dicaffeoyl quinic acids and one coumaric acid ester have also been identified in the methanolic extract of Zulu bush tea [20]. In a similar study comparing with authentic standards, protocatechuic, $p$ coumaric, caffeic and chlorogenic acids from Athrixia phylicoides extracts were identified [5]. In addition, a section of their spectra corresponding to dicaffeoylquinic acids, were also tentatively identified. However, Zulu tea leaves in another study were shown to be devoid of caffeine or pyrrolizidine alkaloids [8]. It has been postulated that the chemical composition of Zulu tea plants is affected by seasonal nitrogen, phosphorous and potassium nutrition [21-25], thus helping to explain the variable findings between researchers.

A subchronic toxicity study of the water extract of $A$. phylicoides was undertaken in rats [26]. No morbidity or mortality was noted, and the biochemical parameters and histopathology of internal organs showed no indication of toxicity. Regarding in vitro studies, it has previously been found that although the water extract of $A$. phylicoides was not toxic to Vero cells at the highest concentration tested of $1 \mathrm{mg} / \mathrm{ml}$ [8], the ethanol extract was relatively more toxic with $\mathrm{IC}_{50}$ values ranging between 100 and $400 \mu \mathrm{g} / \mathrm{ml}$ against Vero cells and brine shrimp larvae $[7,8]$. These $\mathrm{IC}_{50}$ values do not represent significant toxicity. It was however previously reported that four flavonoids isolated from an A. phylicoides ethanol extract were more cytotoxic to Vero cells, with $\mathrm{IC}_{50}$ values as low as $28 \mu \mathrm{g} / \mathrm{ml}$ [7].

Based on traditional use, existing phytochemical knowledge and lack of toxicity, it was decided to screen the plant for antibacterial and antifungal activity using the 
technique of bioautography and to determine which phytochemicals could be extracted with different solvents using HPLC. Bioautography is a useful bioassay for localizing antibacterial or antifungal activity of plant extracts after separation of the constituent compounds on a thin layer chromatography (TLC) plate. Agar overlay methods have been used in the past where an agar medium seeded with test organism is applied directly to the TLC plate $[27,28]$. However, adequate diffusion of active compounds through an aqueous agar matrix may be problematic, particularly in the case of non-polar extracts [29]. In the direct bioautography technique, plant extracts are separated using an appropriate solvent system, the eluting solvent is dried from the TLC plates and then a fine suspension of actively growing bacterial or fungal culture is sprayed on the TLC plate [30]. This method has been modified for use with Candida albicans and Cryptococcus neoformans [31]. Bioautography allows the determination of the number of active compounds in different extracts or fractions, as well as a comparison of inhibition of different micro-organisms by compounds at the same $R_{f}$ values on TLC plates. The occurrence of the same active compounds in different extracts can also be deduced. The strength of the inhibition zone additionally permits comparison to a degree of the relative activities (and hence possibly the relative quantities) of different inhibitory compounds in a plant extract or fraction.

In a recent review on South African herbal teas [32], it was concluded that future research on tea species including Athrixia phylicoides should be directed towards more comprehensive chemical characterisation of extracts, and identification of marker compounds for extract standardisation and quality control. There is little information available on the potential health benefits with regard to antibacterial and antifungal compounds present in $A$. phylicoides, although indications for its traditional use point to possible antimicrobial efficacy. The chemical composition of Athrixia phylicoides has also not been thoroughly studied. The present study was undertaken to address these deficits in knowledge of Athrixia phylicoides prior to further work on commercialization. The differences between chemicals extracted using organic and aqueous solvents were investigated using HPLC and bioautography analysis methods. Using HPLC, the complexity of the plant extracts could be determined, and an indication of the types of chemical compounds present could be provided. In the bioautography analysis, the presence and number of antibacterial and antifungal compounds could be localized on a chromatogram and compared between the extracts prepared using solvents of different polarities.

\section{Methods}

Plant material

Athrixia plant material (aerial parts) was collected and subsequently cut into small pieces and dried in an oven at $30-60^{\circ} \mathrm{C}$. A voucher specimen was deposited in the herbarium of the South African National Botanical Institute (SANBI) in Pretoria (voucher number PRE 592582.0; GENSPEC number 308615). The identity of the plant material was verified by qualified taxonomists based at SANBI, a national reference centre. Dried material was ground to a coarse powder using a hammer mill and stored at ambient temperature prior to extraction.

\section{Preparation of extracts}

The powdered plant material (20 g quantities) was extracted using a variety of solvents spanning a range of polarity, namely diethyl ether (DEE; yield $0.95 \mathrm{~g}, 4.8 \%$ ) (extract 1$)$, dichloromethane/methanol $(\mathrm{DCM} / \mathrm{MeOH}=$ 1:1; yield $1.08 \mathrm{~g}, 5.4 \%$ ) (extract 2), ethyl acetate (EtOAc; yield $1.10 \mathrm{~g}, 5.5 \%$ ) (extract 3 ), ethanol (EtOH; yield $0.88 \mathrm{~g}$, $4.4 \%)$ (extract 4$)$ and room temperature water $\left(\mathrm{H}_{2} 0\right.$; yield $4.40 \mathrm{~g}, 22.0 \%)$ (extract 5 ) in a standard extraction technique. The powdered material was shaken for $30 \mathrm{~min}$ with the extracting solvent (1:10 ratio) and filtered before being dried and stored at $4^{\circ} \mathrm{C}$ until analysis. Saturated solutions of each extract were prepared by adding an aliquot of the dried extracts to the corresponding solvent, sonicating the samples using an Integral Systems Ultrasonic Bath (UMC $20+$ Heater, $50 \mathrm{~Hz}$ ) for 30 minutes and filtering the resulting solutions through a $0.45 \mu \mathrm{m}$ syringe filter. The filtered samples were then analyzed according to a variation of the HPLC method developed by Kamatou and co-workers [33], as well as by thin layer chromatography (TLC) and bioautography [30].

\section{HPLC analysis}

\section{Instrumental conditions for HPLC analysis}

The analysis was done on a Waters Thermabeam (TMD) HPLC system comprising a 2695 Solvent Delivery System, a 2996 PDA detector, column heater and Thermabeam (TMD) EIMS detector. The PDA (photodiode array, nondestructive) detector established the light absorbance spectra from visible and UV wavelengths of each detected compound, while the TMD detector (destructive method) was placed after the PDA in order to generate the corresponding mass spectra. Chromatographic separation was performed on a Phenomenex Gemini C18 column, $250 \times$ $2 \mathrm{~mm}(5 \mu \mathrm{m} \mathrm{125 \textrm {A }})$ maintained at $40^{\circ} \mathrm{C}$. The starting eluent consisted of water containing $10 \mathrm{mM}$ formic acid (FA) (Phase A) and acetonitrile (ACN) (Phase B) in a 90:10 ratio at $0.2 \mathrm{ml} / \mathrm{min}$. The initial gradient table is summarized in Table 1 (screening method 02) but several other methods were tested. The extracts were first evaluated on the Gemini column and thereafter re-analyzed on a Waters Xbridge C18 column $150 \times 2.1 \mathrm{~mm}(3.5 \mu \mathrm{m} \mathrm{110A})$ but replacing the acetonitrile with methanol (Phase C) (screening method 03, Table 2). Both columns were equipped with guard columns of identical packing material and a mechanical filter 
Table 1 Gradient conditions of screening method 02 on the Waters 2695

\begin{tabular}{ccccc}
\hline Time & Flow & \%Phase $\mathbf{A}^{\mathbf{1}}$ & \%Phase B & Curve \\
\hline 0.0 & 0.20 & 90 & 10 & 6 \\
1.0 & 0.20 & 90 & 10 & 6 \\
40.0 & 0.20 & 0 & 100 & 6 \\
45.0 & 0.20 & 0 & 100 & 6 \\
50.0 & 0.20 & 90 & 10 & 3 \\
58.0 & 0.20 & 90 & 10 & 6 \\
59.0 & 0.20 & 90 & 10 & 6 \\
\hline
\end{tabular}

'Phase $\mathrm{A}=$ water with $0.1 \%$ formic acid, Phase $\mathrm{B}=$ acetonitrile.

was inserted to trap any particulate matter or possible precipitates.

The TMD was operated in positive scan mode (50 $650 \mathrm{amu}$ ) with a gain of 10 , the nebulizer temperature was set at $70^{\circ} \mathrm{C}$, the expansion region temperature at $80^{\circ} \mathrm{C}$ and the source temperature at $225^{\circ} \mathrm{C}$. The total volume of post-column eluent was sent to the PDA and TMD detectors. The TMD detector was tuned every day prior to starting analysis and caffeine was injected as a test compound to ensure functionality of the total system.

\section{TLC and bioautography}

\section{Thin layer chromatography (TLC) and phytochemical} analysis

The dried extracts were dissolved in ethanol to a concentration of $10 \mathrm{mg} / \mathrm{ml}$. Chemical constituents of the extracts $(100 \mu \mathrm{g})$ were separated using aluminium-backed TLC plates (Merck, silica gel $60 \mathrm{~F}_{254}$ ). TLC plates were prepared in triplicate and each TLC plate was developed using one of three eluent systems as follows: ethyl acetate: methanol:water (40:5.4:5) [EMW] (polar, neutral); chloroform:ethyl acetate:formic acid (5:4:1) [CEF] (intermediate polarity, acidic); benzene:ethanol:ammonium hydroxide (90:10:1) [BEA] (non-polar, basic) [34]. To completely remove traces of the eluting solvents, the TLC plates were dried under a stream of cold air until there was no solvent smell remaining. The TLC plates were then sprayed with

Table 2 Gradient conditions of screening method 03 on the Waters 2695

\begin{tabular}{ccccc}
\hline Time & Flow & \%Phase $\mathbf{C}^{\mathbf{1}}$ & \%Phase A & Curve \\
\hline 0.0 & 0.20 & 10 & 90 & 6 \\
1.0 & 0.20 & 10 & 90 & 6 \\
40.0 & 0.20 & 100 & 0 & 6 \\
45.0 & 0.30 & 100 & 0 & 6 \\
50.0 & 0.20 & 10 & 90 & 3 \\
58.0 & 0.20 & 10 & 90 & 6 \\
59.0 & 0.20 & 10 & 90 & 6 \\
78.0 & 0.20 & 100 & 0 & 6 \\
\hline
\end{tabular}

${ }^{1}$ Phase $\mathrm{C}=$ methanol, Phase $\mathrm{A}=$ water with $0.1 \%$ formic acid. vanillin-sulphuric acid spray reagent $(0.1 \mathrm{~g}$ vanillin: $28 \mathrm{ml}$ methanol:1 $\mathrm{ml}$ sulphuric acid) and heated at $110^{\circ} \mathrm{C}$ until optimal colour development [35].

\section{Bacterial and fungal cultures}

The bacterial species used were the Gram-negative Escherichia coli (ATCC 25922) and Pseudomonas aeruginosa (ATCC 27853) and the Gram-positive Staphylococcus aureus (ATCC 29213) and Enterococcus faecalis (ATCC 29212). Fungal species included clinical isolates of Candida albicans (from a Gouldian finch) and Cryptococcus neoformans (isolated from a cheetah), which were obtained from the culture collection of the Department of Veterinary Tropical Diseases, University of Pretoria. Bacteria were maintained on Müller-Hinton (MH) agar (Merck) at $4^{\circ} \mathrm{C}$ and were cultured in $\mathrm{MH}$ broth (Fluka) at $37^{\circ} \mathrm{C}$ before use in the bioassays. Fungi were maintained on Sabouraud Dextrose (SD) agar (Fluka) at $4^{\circ} \mathrm{C}$ and were cultured in SD broth (Merck) at $35^{\circ} \mathrm{C}$ and incubated overnight prior to conducting bioautography and microdilution assays.

\section{Bioautography assay}

For each bacterial and fungal test organism used, a set of three TLC plates was prepared as for the TLC analysis above, and allowed to dry completely. The TLC plates were then sprayed with a concentrated suspension of bacterial cells or fungal conidia grown overnight in appropriate broth [30,31]. The TLC plates sprayed with bacterial or fungal suspensions were incubated overnight at $37^{\circ} \mathrm{C}$ or $35^{\circ} \mathrm{C}$ respectively under $100 \%$ relative humidity (in a sealed plastic container) to allow growth of the micro-organism on the plates. The bioautograms were then sprayed with an aqueous solution of $2 \mathrm{mg} / \mathrm{ml} p$-iodonitrotetrazolium violet (INT, Sigma) and incubated at $37^{\circ} \mathrm{C}$ or $35^{\circ} \mathrm{C}$ respectively for approximately four hours until appearance of a red colour showed growth of the microorganisms. Following incubation, the development of clear zones against a red background indicated inhibition of fungal or bacterial growth by bioactive compounds separated on the TLC plates.

\section{Results}

\section{HPLC analysis}

After preliminary trials, optimization of the chromatographic procedure involved 5 extracts $(1-5)$ and two analytical profiles, the first using methanol and a Gemini C18 column (Table 1) and the other using acetonitrile and a Waters Xbridge C18 column (Table 2). In the HPLC analysis of the extracts, the better separation was attained by using the gradient profile "screening method 02" (Table 1). The Waters Xbridge C18 column improved the peak shape of the compounds from those obtained on the Gemini column. The replacement of acetonitrile with methanol improved the resolution of the compounds although co- 
elution was not completely removed using this "screening method 03" (Table 2).

The stacked chromatograms (chromatograms prepared by overlaying chromatographic profiles of extracts separated after several injections) show clearly that no one extracting solvent extracted all phytochemicals seen in the UV chromatograms (Figure 2). In Figure 2 the intensities of the various chromatograms were individually normalised to the largest detected peak.

The chromatograms shown in Figure 2 were overlaid by means of a software facilitated overlay procedure to produce Figure 3. The intensities of the overlaid chromatograms in Figure 3 were then normalized to the large, saturated peak detected in the $\mathrm{DCM} / \mathrm{MeOH}$ extract (extract 2). Figure 3 clearly shows that extracts 1 to 5 contain phytochemicals that were extracted by more than one of the solvent systems used. Except for a few compounds unique to the $\mathrm{H}_{2} \mathrm{O}$ (extract 5) and EtOAc (extract 3) extracts, the majority of compounds were successfully extracted with $\mathrm{EtOH}$ (extract 4). The concentration of the extracted compounds in the EtOH extract was higher than for the other extracting solvents except for the one large peak observed in the $\mathrm{DCM} / \mathrm{MeOH}$ extract (extract 2, red chromatogram). The compounds of the $\mathrm{EtOH}$ extract displayed similar chromatographic behaviour by co-eluting rather than separating into individual compounds, which is an indication of structural similarities, as well as closely related polarities. A comparison of the different peaks found in the $\mathrm{EtOH}$ and $\mathrm{H}_{2} \mathrm{O}$ extracts is shown in Figure 4, where the chromatograms resulting from the two extracts have been overlaid.

Masses of interest in the EtOH extract were sequentially extracted and searched against the NIST mass spectral library. None of the intact glycosides could be detected which was not surprising, as these compounds are labile and not easily detected by classical EI ionisation techniques. A few compounds were tentatively identified, mainly in the EtOH extract, and are listed in Table 3, together with the extracts in which they were detected.

\section{TLC and bioautography analysis}

TLC analysis revealed that extracts 1, 2, 3 and 4 (DEE, $\mathrm{DCM} / \mathrm{MeOH}, \mathrm{EtOAc}$ and $\mathrm{EtOH}$ extracts respectively) had very similar phytochemical profiles, although extracts 1 and 4 appeared the most alike, while extracts 2 and 3 contained lower quantities of certain compounds as evidenced by lighter bands on the chromatograms. Extract 5 (the water extract) was clearly distinct from the other extracts, showing far fewer compounds when TLC plates were sprayed with the vanillin-sulphuric acid spray reagent (Figure 5).

The CEF solvent system was the most efficient at separating the constituent compounds of the extracts $(1-5)$ of

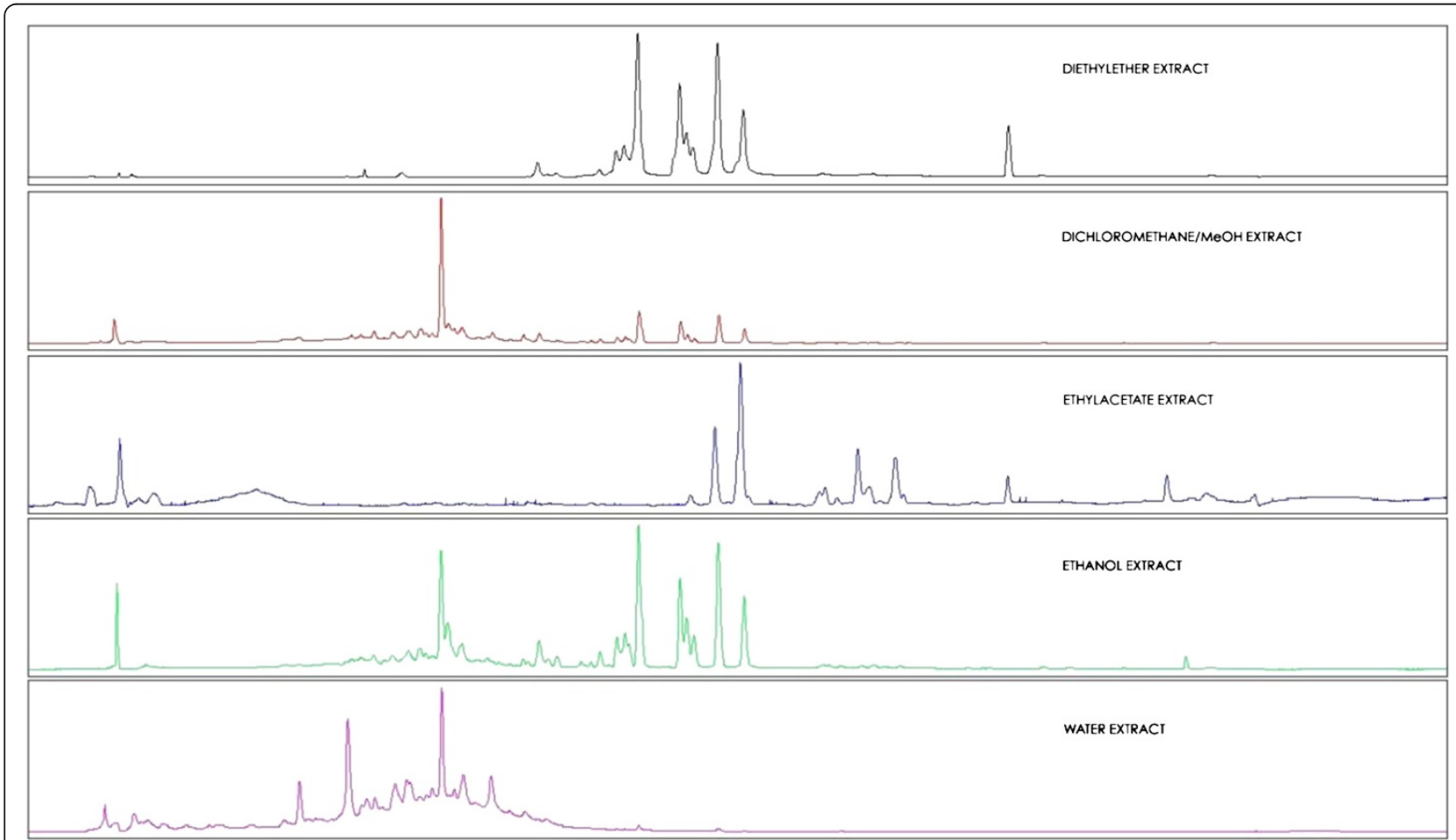

Figure 2 Stacked UV chromatograms $\left(200-600 \mathrm{~nm}\right.$ ) of the five extracts (DEE, DCM/MeOH, EtOAc, EtOH and $\mathrm{H}_{2} \mathrm{O}$ from top to bottom) obtained with screening method 02. 


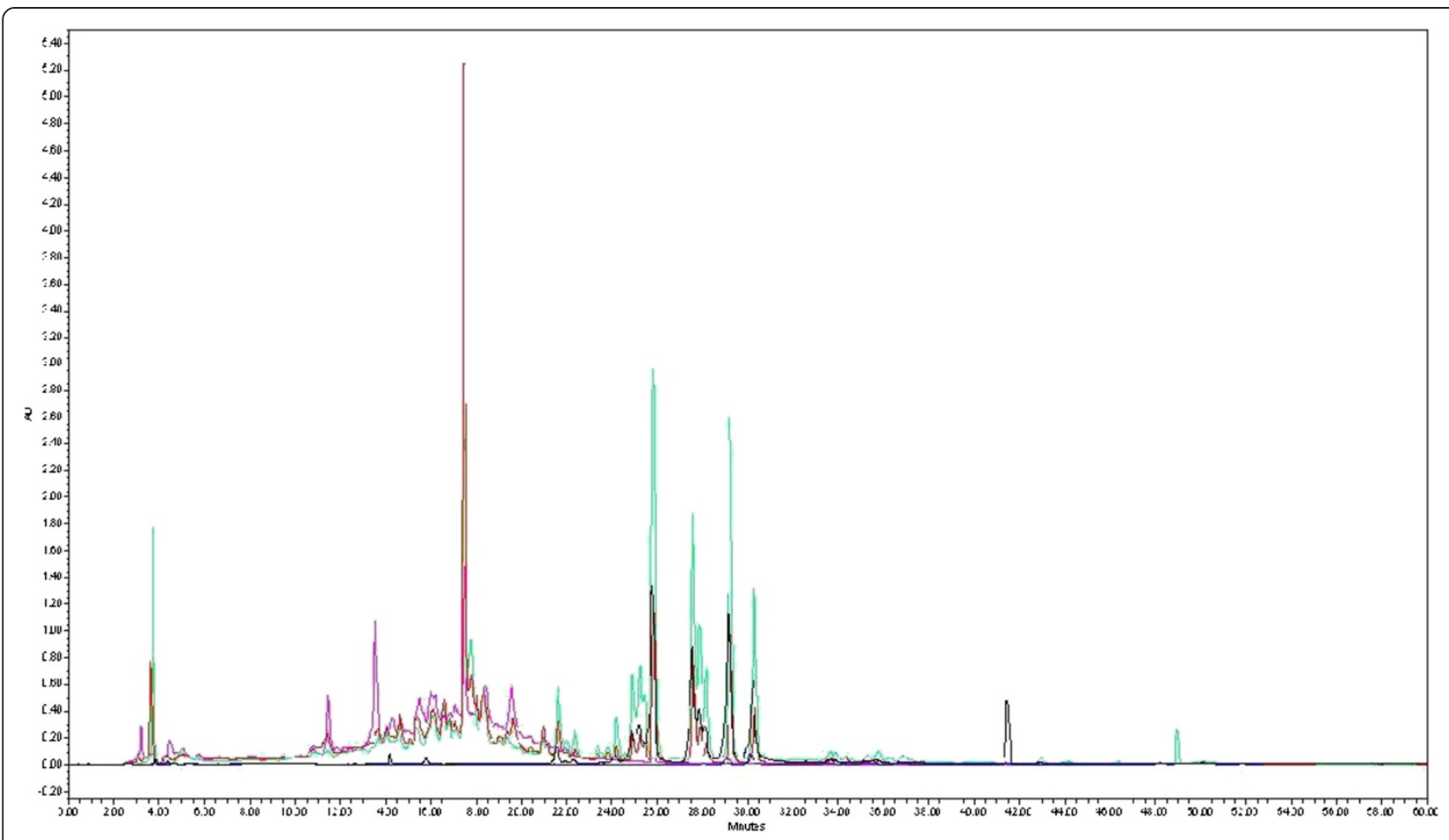

Figure 3 Overlaid UV chromatograms of the five extracts obtained with screening method 02 (Gemini column). Colours of chromatograms: black $=$ DEE extract, red $=\mathrm{DCM} / \mathrm{MeOH}$ extract, blue $=$ EtOAc extract, green $=\mathrm{EtOH}$ extract, pink $=\mathrm{H}_{2} \mathrm{O}$ extract.

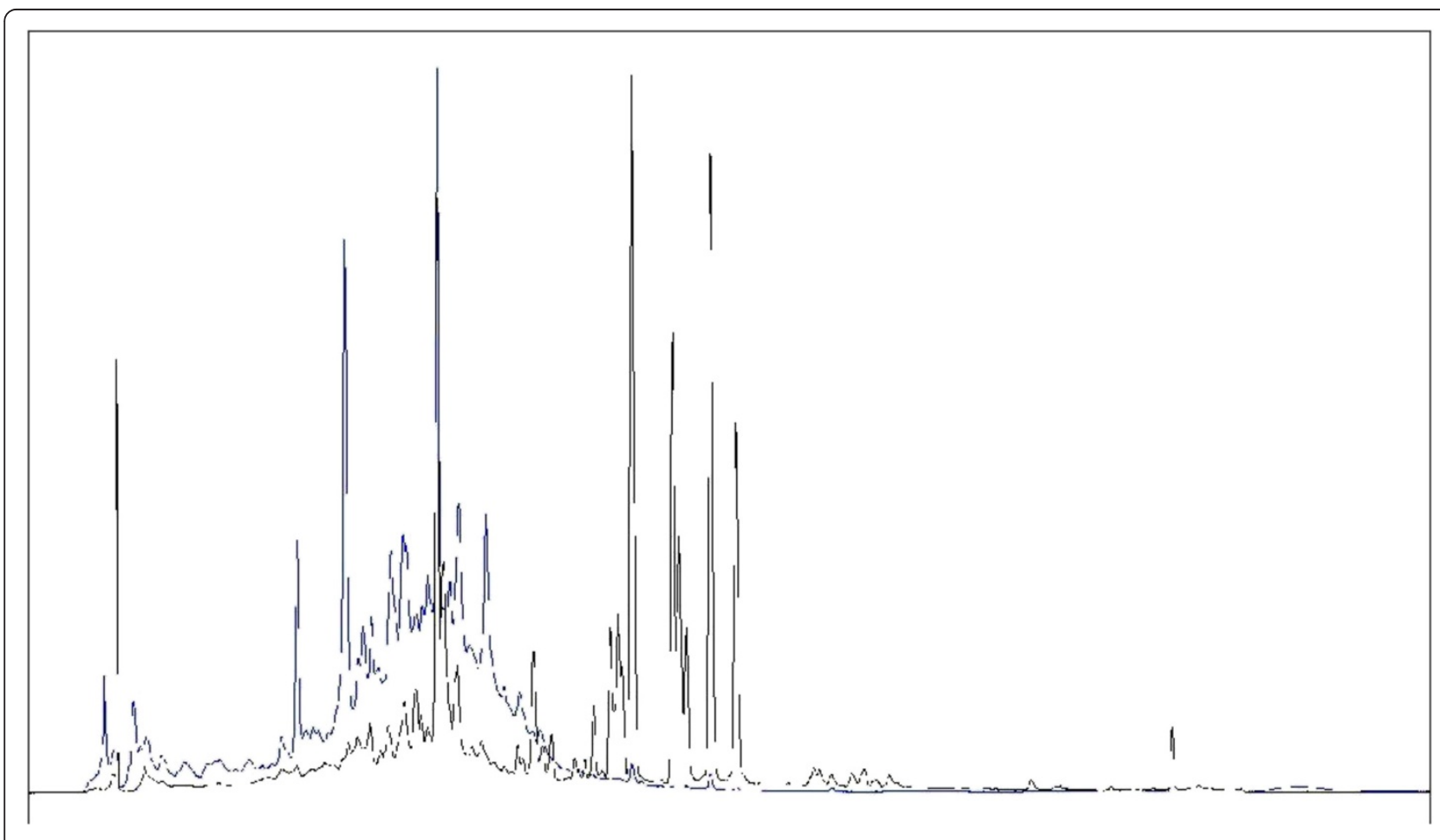

Figure 4 MaxPlot UV chromatograms of the EtOH (black) and $\mathrm{H}_{2} \mathrm{O}$ (blue) extracts (screening method 02). 
Table 3 Identified compounds in Athrixia phylicoides extracts prepared using different solvents

\begin{tabular}{|c|c|c|c|c|c|c|c|}
\hline COMPOUND & FORMULA & MASS & DEE & $\mathrm{DCM} / \mathrm{MeOH}$ & EtOAc & EtOH & $\mathrm{H}_{2} \mathrm{O}$ \\
\hline Inositol & $\mathrm{C}_{6} \mathrm{H}_{12} \mathrm{O}_{6}$ & 180 & $x^{1}$ & $x$ & $x$ & $\sqrt{ }$ & $\sqrt{ }$ \\
\hline Caffeic acid & $\mathrm{C}_{9} \mathrm{H}_{8} \mathrm{O}_{4}$ & 180 & $x$ & $x$ & $x$ & $\sqrt{ }$ & $\sqrt{ }$ \\
\hline Quercetin & $\mathrm{C}_{15} \mathrm{H}_{10} \mathrm{O}_{7}$ & 302 & $x$ & $x$ & $x$ & $\sqrt{ }$ & $x$ \\
\hline Kaempferol & $\mathrm{C}_{15} \mathrm{H}_{10} \mathrm{O}_{6}$ & 286 & $\sqrt{ }$ & $\sqrt{ }$ & X & $\sqrt{ }$ & $x$ \\
\hline Apigenin & $\mathrm{C}_{15} \mathrm{H}_{10} \mathrm{O}_{5}$ & 270 & $x$ & $\sqrt{ }$ & $x$ & $\sqrt{ }$ & $x$ \\
\hline Hymenoxin & $\mathrm{C}_{19} \mathrm{H}_{48} \mathrm{O}_{8}$ & 374 & $\sqrt{ }$ & $\sqrt{ }$ & $\sqrt{ }$ & $\sqrt{ }$ & $x$ \\
\hline Oleanolic acid & $\mathrm{C}_{30} \mathrm{H}_{48} \mathrm{O}_{3}$ & 456 & $x$ & $x$ & $x$ & $\sqrt{ }$ & $x$ \\
\hline 7,7'-Dihydroxy-8,8'-dimethoxy-3,3'-dimethyl-2,2'-binaphthalene-1,1',4,4'-tetrone & $\mathrm{C}_{24} \mathrm{H}_{18} \mathrm{O}_{8}$ & 434 & $\sqrt{ }$ & $\sqrt{ }$ & $\sqrt{ }$ & $\sqrt{ }$ & $\sqrt{ }$ \\
\hline Scaposin & $\mathrm{C}_{19} \mathrm{H}_{18} \mathrm{O}_{9}$ & 390 & $\sqrt{ }$ & $\sqrt{ }$ & $x$ & $\sqrt{ }$ & $\sqrt{ }$ \\
\hline
\end{tabular}

${ }^{1} \mathrm{X}=$ absent, $\sqrt{ }=$ present.

all the solvent systems used (EMW, CEF and BEA) as shown by a greater number of separated bands for each extract. With the polar EMW solvent system, all the visible active zones separated poorly and appeared close to the solvent front of the TLC chromatogram, indicating that the active compounds were relatively non-polar (results not shown). The polar BEA solvent system was also less efficient than the CEF, with active zones appearing at Rf values below 0.5 in almost all cases (data not shown).

\section{Bioactivity}

Bioactivity against the Gram-positive E. faecalis in the CEF eluting solvent system (for extracts 1 - 4) was detected at the bands with $R_{\mathrm{f}}=0.59$ and 0.71 , correlating to brownish-yellow compounds, and also at bands of $R_{\mathrm{f}}=$ 0.84 and 0.89 , corresponding to reddish-pink compounds suggestive of flavanol-type compounds in the reference TLC plate (Table 4) sprayed with vanillin spray reagent. Vanillin is an aromatic aldehyde which reacts with the metasubstituted ring of flavanols to yield a red adduct [36]. No zones of inhibition against E. faecalis could be seen in extract 5 . An example of a TLC plate sprayed with E. faecalis as test organism, and a reference TLC plate sprayed with vanillin-sulphuric acid spray reagent, is shown in Figure 5.

Pronounced antibacterial activity against the Grampositive $S$. aureus was noted at the bands at $R_{\mathrm{f}}=0.58$, $0.64,0.72$ and 0.89 in extract 4 when using CEF as the eluting system (Table 3). These compounds (yellowbrown and pink) were also visible in extracts 1, 2 and 3, although they were not as distinct. No clear zones of inhibition against $S$. aureus could be seen in extract 5 .

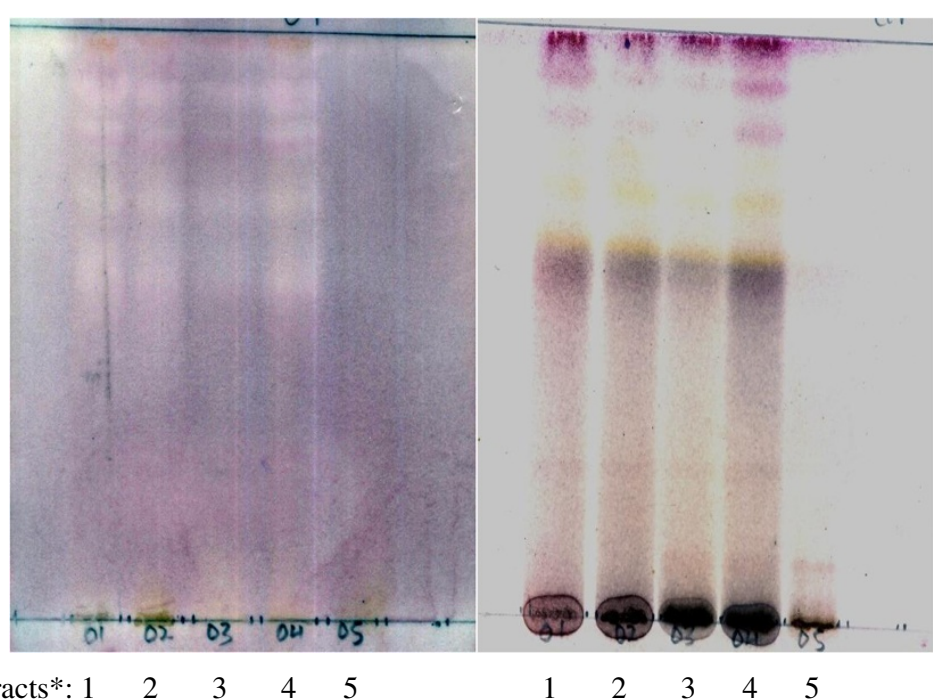

Figure 5 TLC plates eluted in CEF solvent system (chloroform:ethyl acetate:formic acid = 5:4:1) and sprayed with Enterococcus faecalis (left) and vanillin-sulphuric acid spray reagent (right). The solvent fronts and origins are marked with pencil lines at the top and bottom of the TLC plates respectively. ${ }^{*}$ Extracts: $1=\mathrm{DEE}$ extract, $2=\mathrm{DCM} / \mathrm{MeOH}$ extract, $3=\mathrm{EtOAc}$ extract, $4=\mathrm{EtOH}$ extract, $5=\mathrm{H}_{2} \mathrm{O}$ extract. 
Table $4 \mathbf{R}_{\mathrm{f}}$ values of zones of bacterial and fungal growth inhibition by Athrixia extracts when separated by TLC with CEF as eluent

\begin{tabular}{|c|c|c|c|c|c|c|c|c|c|c|c|}
\hline \multicolumn{2}{|c|}{$R_{f}$ value } & \multicolumn{2}{|c|}{ E. coli ${ }^{a}$} & \multicolumn{2}{|c|}{ E. faecalis } & \multicolumn{2}{|c|}{ S. aureus } & \multicolumn{2}{|c|}{ C. albicans } & \multicolumn{2}{|c|}{ C. neoformans } \\
\hline & Extracts $^{\mathrm{b}}$ : & $1-4$ & 5 & $1-4$ & 5 & $1-4$ & 5 & $1-4$ & 5 & $1-4$ & 5 \\
\hline $0.58^{1}$ & Yellow-brown & $-{ }^{4}$ & - & - & - & $\sqrt{ }$ & - & - & - & - & - \\
\hline $0.59^{1}$ & Yellow-brown & - & - & $\sqrt{ }$ & - & - & - & $\sqrt{ }$ & $\sqrt{ }$ & $\sqrt{ }$ & - \\
\hline 0.64 & Yellow-brown & $\sqrt{ }$ & - & - & - & $\sqrt{ }$ & - & - & - & - & - \\
\hline $0.70^{2}$ & Yellow-brown & $\sqrt{ }$ & - & - & - & - & - & - & - & $\sqrt{ }$ & - \\
\hline $0.71^{2}$ & Yellow-brown & - & - & $\sqrt{ }$ & - & - & - & - & - & - & - \\
\hline $0.72^{2}$ & Yellow-brown & - & - & - & - & $\sqrt{ }$ & - & $\sqrt{ }$ & - & - & - \\
\hline 0.84 & Pink & $\sqrt{ }$ & - & $\sqrt{ }$ & - & - & - & - & - & - & - \\
\hline $0.89^{3}$ & Pink & - & - & $\sqrt{ }$ & - & $\sqrt{ }$ & - & - & - & - & - \\
\hline $0.91^{3}$ & Pink & $\sqrt{ }$ & $\sqrt{ }$ & - & - & - & - & - & - & - & - \\
\hline
\end{tabular}

Using CEF as eluent, several bioactive zones on the TLC plate could be distinguished against $E$. coli (Gram-negative) in extracts 1 to 4 , at $R_{\mathrm{f}}=0.64,0.70,0.84$ and 0.91 . The first two zones $\left(R_{\mathrm{f}}=0.64\right.$ and 0.70$)$ appeared to correlate with brownish-yellow spots while the other two active compounds correlated with pink bands on the vanillin-sprayed reference plate. The active zone at $\mathrm{R}_{\mathrm{f}}=0.91$ was also detected in the extract 5 . It should be noted that the "-" signs in Table 4 refer to lack of activity of individual compounds eluting on the TLC plates at those particular Rf values, and do not indicate lack of activity of the entire extract, as compounds eluting at other $\mathrm{Rf}$ values may show activity. No activity was detected against the Gram-negative $P$. aeruginosa (results not shown).

Antifungal activity after eluting in the CEF solvent system against Candida albicans was noted with the zone at $R_{\mathrm{f}}=0.59$ in all five extracts (less distinct in extract 5), and a very faint possible zone of activity occurred at $R_{f}=$ 0.72 in extracts 1 to 4 . These zones both correlated with brownish-yellow bands on the reference TLC plate. Antifungal activity (also in the CEF solvent system) against Cryptococcus neoformans was noted with the band at $\mathrm{R}_{\mathrm{f}}=$ 0.59 and 0.70 in extracts $1-4$. These bands were brownishyellow in the reference TLC plate. It was difficult to distinguish whether there was any activity against Cryptococcus neoformans in extract 5 .

In summary, it appears that compounds at the same $R_{\mathrm{f}}$ values of approximately 0.58 (brownish-yellow), 0.72 (brownish-yellow) and 0.89 (pink) were active against the Gram-positive test organisms E. faecalis and S. aureus. A brownish-yellow compound at $\mathrm{R}_{\mathrm{f}}=0.64$ was active against $S$. aureus but not against E. faecalis, and a pink compound at $\mathrm{R}_{\mathrm{f}}=0.84$ was active against $E$. faecalis but not $S$. aureus.
No zones of inhibition against Gram-positive bacteria were apparent in extract 5.

The same brownish-yellow compounds at $R_{f}=0.64$ and 0.71 in extracts $1-4$ that were active against the Gram-positive bacteria were also active against the Gram-negative E. coli. The pink band at $\mathrm{R}_{\mathrm{f}}=0.84$ in extracts 1-4 was active against both $E$. coli and Grampositive E. faecalis. A further pink band at approximately $\mathrm{R}_{\mathrm{f}}=0.90$ was active against $E$. coli as well as both Grampositive species, and this active zone was also seen in extract 5 against $E$. coli. No antibacterial activity was noted against the Gram-negative $P$. aeruginosa in the bioautography assays.

\section{Discussion}

The traditional ways of preparing a herbal tea involve boiling plant material in water to yield a decoction or soaking plant material in freshly boiled water to produce an infusion. In addition, for some plants, in the hands of 'more experienced' traditional herbalists, a pre-layup process is carried out prior to producing the water infusion (J Olivier, personal communication). This pre-layup process often involves carrying plant material around on their heads under some kind of hat, with the resultant fermentation possibly following an 'ethanol-type' extraction process.

In this study, the ethanol extract produced a more complex mixture of compounds than the water extract, especially of intermediate polarity, as there were significantly more bands in the TLC chromatogram for the ethanol extract when compared to those visualized in the water extract (Figure 5). Although some observed peaks correlated between the water and ethanol extracts 
in the HPLC analysis (Figure 4), the two extracts differed significantly, which raises the question regarding the difference in herbal/medicinal potency, as well as toxicity, between the two extracts. The bioactivity of the organic solvent extracts $(1-4)$ appears to have been similar and the toxicity of the extracts could be explored in future work. It was previously reported that ethanol extracts were more toxic than aqueous $A$. phylicoides extracts [8]. Many investigations have shown that aqueous extracts are less toxic than ethanol extracts [37-39]. Chemicals found in the ethanol extract in this study included quercetin, kaempferol, apigenin, hymenoxin and oleanolic acid (Table 3). The compounds quercetin [40], kaempferol [41], apigenin [42] and oleanolic acid [43] do not appear to be associated with toxicity but higher doses of flavonoids may have prooxidant activity and hence may be implicated in cytotoxicity [42]. However, the sesquiterpene lactone, hymenoxin, is potentially toxic $[44,45]$, and the presence of this compound in the ethanol extract may contribute to the reported toxicity of this extract.

In another study [46], it was found that fermented water infusions of rooibos tea (Aspalathus linearis) were more effective in combating the growth of Escherichia coli than the unfermented rooibos extract. Zulu tea (Athrixia phylicoides) is not fermented before preparation, but this is an aspect that could be investigated in the future to provide different tastes for evaluation prior to potential commercialization, particularly if fermentation results in an improved taste or a different chemical composition which may enhance health benefits.

In earlier research, it was discovered that infusions and decoctions prepared following traditional methods and laboratory-prepared cold aqueous extracts of $A$. phylicoides were similar in terms of selected phytochemical composition, antioxidant activity and cytotoxicity [8]. In the present study therefore, the same procedure was followed for preparing the organic and aqueous extracts for comparison purposes in this study. It would be interesting to conduct further studies, including HPLC, TLC and bioautography, on the different types of aqueous extracts, namely infusions, decoctions and cold aqueous extracts.

The bioautography screen was a worthwhile bioassay that provided very useful information which has indicated the presence of several antimicrobial phytochemicals and has given justification to further study this plant species as a new antibacterial and antifungal agent. The ethanolic extract of Athrixia phylicoides is a complex mixture of polyphenolics, as indirectly indicated by the reddish-pink colour of bands in bioautography, together with other compounds with a range of solubility and chromatographic behaviour. Various compounds were detected that displayed a flavonoid-type substructure as evaluated from the UV spectra. These compounds could possibly be the same flavonoids as previously isolated from the ethanol extract of $A$. phylicoides, which included the known flavonoids 5-hydroxy-6,7,8,3',4',5' -hexamethoxyflavon-3-ol, 30-demethyldigicitrin, 5,6,7,8,3', $4^{\prime}$-hexamethoxyflavone and quercetin, or similar flavonoids [7]. To separate the compounds in the ethanol extract fully might require a more polar stationary phase, or the utilisation of a more advanced chromatographic system as well as a more comprehensive spectral library.

In this study, the organic extracts (1-4) of A. phylicoides all showed similar phytochemical profiles, with similar compounds showing bioactivity against the various microorganisms. The water extract had a distinct TLC profile, with few visible compounds, with one compound near the solvent front active against $E$. coli and a different compound active against Candida albicans. In the CEF solvent system, which is an intermediate polarity system, the active compounds had $R_{f}$ values greater than 0.5 , indicating that the active compounds tended to be more non-polar. As the compounds detected in the HPLC analysis were of a relatively polar nature (as they did not elute early in the HPLC separation), it is possible that the active compounds (Table 4) are not the same as those identified (Table 3). This is the first report of bioautography assays of $A$. phylicoides extracts. It is now confirmed that there are several potent antibacterial and antifungal compounds in Athrixia phylicoides and this justifies the need for further research.

Compounds with broad spectrum antibacterial and antifungal activity, as well as those with more selective activity, were detected in the plant extracts. Gram-positive bacteria are generally more sensitive to drug action than Gramnegative bacteria [29], mainly owing to differences in their cell wall composition, and this was shown in the case of $P$. aeruginosa, which was resistant to $A$. phylicoides extracts. The selective activity, or lack of toxicity, of active compounds in tea extracts is an important aspect to investigate, particularly as the herbal tea industry is less willing to accept evidence of traditional use as an indication of safety [32].

In the current study, two complementary methodologies, namely bioautography and HPLC analysis, were used to obtain an indication of the bioactivity of different extracts and the identity of some of the chemical compounds in the same extracts. Future work should focus on isolating the bioactive compounds using bioassay-guided fractionation followed by NMR and MS analysis to identify the purified constituents. Bioautography is an extremely useful technique to guide fractionation for isolation of antibacterial and antifungal constituents from plant extracts. During the fractionation process, HPLC traces of the fractions may be compared to the bioautography chromatograms to explore correlations between bioactive compounds and the presence of HPLC peaks. Much further research needs to be conducted on the bioactivity and toxicity of compounds in Athrixia bush tea. 


\section{Conclusions}

In this study, a number of extracts of Athrixia phylicoides aerial parts were prepared using various organic solvents and water. The organic extracts $(1-4)$ had more complex phytochemical profiles (Figures 2, 3, 4, Table 3) and a higher number of antimicrobial compounds (Figure 5, Table 4) than the aqueous extract (5) as demonstrated by comparing the HPLC spectra with the TLC and bioautography results. It is imperative to know more about the composition of Zulu tea extracts and how this relates to bioactivity and bioavailability, for the purpose of enhancing beneficial aspects when sourcing plant material for cultivation purposes, and for use as chemical or biological markers for standardisation.

\section{Abbreviations \\ ACN: Acetonitrile; BEA: Benzene:ethanol:ammonium hydroxide (90:10:1); CEF: Chloroform:ethyl acetate:formic acid (5:4:1); DCM: Dichloromethane; DEE: Diethyl ether; EIMS: Electron Impact ionization Mass Spectrometry; EMW: Ethyl acetate:methanol:water (40:5.4:5); EtOAc: Ethyl acetate; EtOH: Ethanol; FA: Formic acid; HPLC: High pressure liquid chromatography; MeOH: Methanol; MIC: Minimal inhibitory concentration; MS: Mass Spectrometry; NMR: Nuclear magnetic resonance; TLC: Thin layer chromatography.}

\section{Competing interests}

The authors declare that they have no competing interests.

\section{Authors' contributions}

LJM assisted with designing the study, performed some of the TLC and bioautography experiments, drafted sections of the manuscript and edited the final version. VPB performed most of the TLC and bioautography. MSM designed the study and wrote sections of the paper. PS and GF conducted the HPLC analysis and wrote the relevant sections of the paper. JO contributed plant material and advice in designing and performing the study, and JNE provided advice and facilities for conducting the TLC and bioautography. All authors contributed to editing the manuscript. All authors read and approved the final manuscript.

\section{Acknowledgements}

The reliable help of J Senabe in preparing the initial extracts from dried Athrixia material is gratefully acknowledged. The National Research Foundation (NRF) of South Africa provided financial assistance. Prof Alvaro Viljoen (Tshwane University of Technology) provided a photograph of A. phylicoides.

\section{Author details \\ ${ }^{1}$ Department of Paraclinical Sciences, Phytomedicine Programme, Faculty of Veterinary Science, University of Pretoria, Private Bag X04, Onderstepoort 0110, South Africa. ${ }^{2}$ Present address: Department of Biochemistry, Microbiology and Biotechnology, University of Limpopo, Private Bag X1106, Sovenga 0727, South Africa. ${ }^{3}$ Biosciences, Council for Scientific and Industrial Research, PO Box 395, Pretoria, Gauteng 0001, South Africa. ${ }^{4}$ Department of Biochemistry, University of Johannesburg, Auckland Park 2006, South Africa. ${ }^{5}$ Department of Geography, Geoinformatics and Meteorology, University of Pretoria, Private Bag X20, Hatfield 0028, South Africa.}

Received: 31 December 2012 Accepted: 10 December 2013 Published: 13 December 2013

\section{References}

1. Leistner OA: Seed plants of southern Africa: families and genera. Strelitzia 10. Pretoria: National Botanical Institute; 2000.

2. Pooley E: A field guide to wild flowers of KwaZulu-Natal and the Eastern region. Durban: Natal Flora Publications Trust; 1998:442.

3. Mudau FN, Araya HT, du Toit ES, Soundy P, Olivier J: Bush tea (Athrixia phylicoides DC.) as an alternative herbal and medicinal plant in southern Africa: opportunity for commercialization. Med Aromat Plant Sci Biotechnol 2007, 1:70-73.
4. Rampedi I, Olivier J: The use and potential commercial development of Athrixia phylicoides. Acta Academica 2005, 37:165-183.

5. de Beer D, Joubert E: Antioxidant potential and phenolic composition of bush tea (Athrixia phylicoides) extracts. In Abstracts of Indigenous Plant Use Forum. Johannesburg, South Africa; 2007:30.

6. Mavundza EJ, Tshikalange TE, Mudau FN, Meyer JJM: Evaluation of antibacterial and antioxidant activities in ethanol extract of wild bush tea (Athrixia phylicoides (DC.)). Med Aromat Plant Sci Biotechnol 2007, 1:240-242.

7. Mavundza EJ, Tshikalange TE, Lall N, Mudau FN, Hussein AA: Antioxidant activity and cytotoxicity of three flavonoids from Athrixia phylicoides ethanol extract. S Afr J Bot 2010, 76:398.

8. McGaw LJ, Steenkamp V, Eloff JN: Evaluation of Athrixia bush tea for cytotoxicity, antioxidant activity, caffeine content and presence of pyrrolizidine alkaloids. J Ethnopharmacol 2007, 110:16-22.

9. Padayachee K: The phytochemistry and biological activities of Athrixia phylicoides. Johannesburg, South Africa: MSc Med. Thesis. University of the Witwatersrand; 2010

10. Hutchings A, Scott AH, Lewis G, Cunningham A: Zulu Medicinal Plants: An Inventory. Pietermaritzburg, South Africa: University of Natal Press; 1996.

11. Mabogo DEN: The ethnobotany of the Vhavenda. Pretoria, South Africa: MSC Thesis, University of Pretoria; 1990.

12. Watt JM, Breyer-Brandwijk MG: Medicinal and Poisonous Plants of Southern and Eastern Africa. 2nd edition. Edinburgh: Livingstone; 1962.

13. Rakuambo ZJ: Indigenous knowledge of bush tea (Athrixia phylicoides) and effect of fertigation frequency and growing medium on plant growth. Pretoria, South Africa: M.Inst. Agrar Thesis, University of Pretoria; 2007.

14. van Wyk B-E, Gericke N: People's Plants. Pretoria, South Africa: Briza; 2000.

15. de Beer D, Joubert E, Malherbe CJ, Brand DJ: Use of countercurrent chromatography during isolation of 6-hydroxyluteolin-7-O-B-glucoside, a major antioxidant of Athrixia phylicoides. J Chromatogr A 2011, 1218:6179-6186.

16. Mogotlane ID, Mudau FN, Mashela PW, Soundy P: Seasonal responses of total antioxidant contents in cultivated Bush Tea (Athrixia phylicoides L.) leaves to fertilizer rates. Medicinal Aromatic Plant Sci Biotech 2007, 1:77-79.

17. Chellan N, Muller CJF, de Beer D, Joubert E, Page BJ, Louw J: An in vitro assessment of the effect of Athrixia phylicoides DC. aqueous extract on glucose metabolism. Phytomedicine 2012, 19:730-736.

18. Bohlmann F, Zdero C: Neue norkauren- und thymol-derivate aus Athrixiaarten. Phytochem 1977, 16:1773-1776.

19. Mashimbye MJ, Mudau FN, Soundy P, van Ree T: A new flavonol from Athrixia phylicoides (bush tea). S Afr J Chem 2006, 59:1-2.

20. Reichelt KV, Hoffmann-Luecke P, Hartmann B, Weber B, Ley JP, Krammer GE, Swanepoel KM, Engel K-H: Phytochemical characterization of South African bush tea (Athrixia phylicoides DC.). S Afr J Bot 2012, 83:1-8.

21. Mudau FN: Growth, development and chemical composition of bush tea (Athrixia phylicoides L.) as affected by seasonal nitrogen, phosphorus and potassium nutrition. Pretoria, South Africa: PhD Thesis, University of Pretoria; 2006.

22. Mudau FN, Soundy P, du Toit ES, Olivier J: Variation in polyphenolic content of Athrixia phylicoides (L.) (bush tea) leaves with season and nitrogen application. S Afr J Bot 2006, 72:398-402.

23. Chabeli PM, Mudau FN, Mashela PW, Soundy P: Effects of nitrogen, phosphorus and potassium nutrition on seasonal tannin content of bush tea (Athrixia phylicoides DC.). S Afr J Plant \& Soil 2013, 25:79-83.

24. Mudau FN, Soundy P, du Toit ES: Effects of nitrogen, phosphorus, and potassium nutrition on total polyphenol content of bush tea (Athrixia phylicoides L.) leaves in a shaded nursery environment. Hortscience 2007, 42:334-338

25. Mudau FN, Soundy P, du Toit ES: Nitrogen, phosphorus, and potassium nutrition increases growth and total polyphenol concentrations of bush tea in a shaded nursery environment. Horttechnology 2007, 17:107-110.

26. Chellan N, de Beer D, Muller C, Joubert E, Louw J: A toxicological assessment of Athrixia phylicoides aqueous extract following sub-chronic ingestion in a rat model. Human Exp Toxicol 2008, 27:819-825.

27. Hamburger MO, Cordell GA: A direct bioautographic TLC assay for compounds possessing antibacterial activity. J Nat Prod 1987, 50:19-22.

28. Rahalison L, Hamburger M, Hostettmann K, Monod M, Frenk E: A bioautographic agar overlay method for the detection of antifunga compounds from higher plants. Phytochem Anal 1991, 2:199-203.

29. Cos P, Vlietinck AJ, Vanden Berghe D, Maes L: Anti-infective potential of natural products: how to develop a stronger in vitro 'proof-of-concept'. J Ethnopharmacol 2006, 106:290-302. 
30. Begue WJ, Kline RM: The use of tetrazolium salts in bioautographic procedures. J Chromatogr 1972, 64:182-184.

31. Masoko P, Eloff JN: The diversity of antifungal compounds of six South African Terminalia species (Combretaceae) determined by bioautography. Afr J Biotechnol 2005, 4:1425-1431.

32. Joubert E, Gelderblom WCA, Louw A, de Beer D: South African herbal teas: Aspalathus linearis, Cyclopia spp. and Athrixia phylicoides-A review. J Ethnopharmacol 2008, 119:376-412.

33. Kamatou GPP, Viljoen AM, Gono-Bwalya AB, van Zyl RL, van Vuuren SF, Lourens ACU, Başer KHC, Demirci B, Lindsey KL, van Staden J, Steenkamp P: The in vitro pharmacological activities and a chemical investigation of three South African Salvia species. J Ethnopharmacol 2005, 102:382-390.

34. Kotze M, Eloff JN: Extraction of antibacterial compounds from Combretum microphyllum (Combretaceae). S Afr J Bot 2002, 68:62-67.

35. Wagner H, Bladt S: Plant Drug Analysis: A Thin Layer Chromatography Atlas. 2nd edition. Berlin: Springer-Verlag; 1996.

36. Hagerman AE: Vanillin Assay. http://www.users.muohio.edu/hagermae/ Vanillin\%20Assay.pdf (accessed 4 July 2013).

37. Devi PU, Ganasoundari A: Radioprotective effect of leaf extract of Indian medicinal plant Ocimum sanctum. Indian J Exp Biol 1995, 33:205-208.

38. Aina SA, Banjo AD, Lawal OA, Okoh HI, Aina OO, Dedeke GA: The toxicity of extracts of Tetrapleura tetraptera (Aridan), Delonix regia (Flame of the Forest) and Raphia vinifera (Raffia Palm) on the larvae of Anopheles gambiae. Acad J Entomol 2009, 2:67-70.

39. Tarkang PA, Agbor GA, Armelle TD, Ramthe TLR, David K, Ngadena YSM: Acute and chronic toxicity studies of the aqueous and ethanol leaf extracts of Carica papaya Linn in Wistar rats. J Nat Prod Plant Resour 2012, 2:617-627.

40. Harwood M, Danielewska-Nikiel B, Borzelleca JF, Flamm GW, Williams GM, Lines TC: A critical review of the data related to the safety of quercetin and lack of evidence of in vivo toxicity, including lack of genotoxic/ carcinogenic properties. Food Chem Toxicol 2007, 45:2179-2205.

41. Chen AY, Chen YC: A review of the dietary flavonoid, kaempferol on human health and cancer chemoprevention. Food Chem 2013, 138:2099-2107.

42. Tsuji PA, Walle T: Cytotoxic effects of the dietary flavones chrysin and apigenin in a normal trout liver cell line. Chem Biol Interact 2008, 171:37-44.

43. Liu J: Pharmacology of oleanolic acid and ursolic acid. J Ethnopharmacol 1995, 49:57-68.

44. The Merck Veterinary Manual for Veterinary Professionals. http://www merckmanuals.com/vet/search.html?qt=hymenoxin\&start=1\&context=\% 2Fvet (accessed 27 September 2013).

45. The Food and Environment Research Agency: https://secure.fera.defra.gov. uk/treechemicals/review/metabolites.cfm (accessed 27 September 2013).

46. Scheepers S: Anti-microbial activity of rooibos tea (Aspalathus linearis) on food spoilage organisms and potential pathogens. Stellenbosch, South Africa: M.Sc. (Food Science) Thesis. Stellenbosch University; 2001.

\section{Submit your next manuscript to BioMed Central and take full advantage of:}

- Convenient online submission

- Thorough peer review

- No space constraints or color figure charges

- Immediate publication on acceptance

- Inclusion in PubMed, CAS, Scopus and Google Scholar

- Research which is freely available for redistribution 